\title{
Penerapan Model Pembelajaran Quantum Learning di Lembaga Pendidikan Anak Usia Dini
}

\author{
Mardi Fitri \\ UIN Sunan Kalijaga Yogyakarta \\ Jl. Laksda Adisucipto, Papringan, Caturtunggal, Kec. Depok, Kabupaten Sleman, Daerah \\ Istimewa Yogyakarta \\ Email:mardifitri068@gmail.com
}

$$
\text { Naskah diterima: } 5 \text { Juni 2020, direvisi: } 6 \text { Septem ber 2020, diterbitkan: } 23 \text { September 2020 }
$$

\begin{abstract}
Abstrak
Para pelajar selama ini kurang termotivasi dalam kegiatan pembelajaran, dikarenakan model yang diterapkan selama ini dianggap tidak menarik dan membosankan bagi para pelajar, khususnya di lembaga PAUD. Para guru kurang peka terhadap kebutuhan para pelajar nya, sehingga mereka tidak dapat menyuguhkan model pembelajaran yang tepat seperti yang diinginkan oleh para pelajar. Seharusnya model pembelajaran untuk anak usia dini itu dirancang sesuai dengan keperluannya, agar proses pembelajaran yang berlangsung menja di lebih menyenangkan. Maka diperlukan nya suatu model pembelajaran yang sesuai juga menyenangkan bagi setiap anak. Salah satu contoh model pembelajaran yang dapat diterapkan di lembaga PAUD adalah model pembelajaran quantum learning. Penelitian ini bertujuan (1) untuk mengetahui bagaimana konsep penerapan model quantum learning pada pembelajaran anak usia dini (2) untuk mengetahui manfaat dalam penerapan model quantum learning pada pembelajaran anak usia dini. Metode penelitian yang digunakan dalam penelitian ini berupa studi pustaka atau librabry research. Hasil penelitian menunjukkan bahwa keberhasilan pembelajaran quantum tergantung pada kemampuan guru dalam memahami konsep dan mengimplementasikan langkah-langkah pembelajaran quantum dalam kegiatan pembelajarannya.
\end{abstract}

Kata kunci: model pembelajaran quantum learning, pembelajaran aktif, pendidikan anak usia dini

\section{Abstract}

Students have so far been less motivated in learning activities, because the model applied so far is considered unattractive and boring for students, especially in Early Childhood Education institutions. Teachers are less 
sensitive to the needs of their students, so they cannot present the exact learning model that students want. The learning model for early childhood should be designed according to its needs, so that the learning process that takes place becomes more enjoyable. Then it takes an appropriate learning model that is also fun for every child. One example of a learning model that can be applied in Early Childhood Education Institutions is the quantum learning learning model. This study aims (1) to find out how the concept of implementing a quantum learning model in early childhood learning (2) to determine the benefits of implementing a quantum learning model in early childhood learning. The research method used in this research is literature study or library research. The results showed that the success of quantum learning depends on the ability of teachers to understand the concept and implement quantum learning steps in their learning activities.

Keywords: active learning, early childhood education, quantum learning model

\section{Pendahuluan}

Pendidikan Anak Usia Dini (PAUD) merupakan suatu proses tentang usaha pembinaan yang diperuntukkan untuk anak yang baru lahir hingga berumur 6 tahun yang dilaksanakan dengan cara memberikan stimulasi pendidikan, sebagai bentuk bantuan bagi perkembangan maupun pertumbuhan dari segi fisik ataupun psikologisnya yang bertujuan supaya anak mempunyai modal awal dalam memasuki jenjang pendidikan selanjutnya. Pendidikan yang di lakukan di PAUD bertujuan agar dapat mengembangkan diri, pengetahuan, ataupun kemampuan yang dimiliki yang berlandas kan pada pendidikan dasar serta mengembangkan diri secara optimal seperti asas pendidikan sedini mungkin dan seumur hidup (Shofa \& Suparno, 2014, hlm. 210). PAUD itu sangat penting bagi seorang anak, sebab PAUD merupakan pondasi awal atau kunci keberhasilan di masa depan. Selain itu PAUD juga sebagai salah satu tempat untuk mempersiapkan SDM yang berkualitas, sehingga penting untuk mempersiapkan segala sesuatu yang dibutuhkan dalam penyelenggaraan proses PAUD. Anak usia dini tidak sama seperti layak nya orang dewasa, maka pembelajaran yang ada di PAUD pun harus dideasain sama seperti kebutuhan anak usia dini, dan yang paling penting pembelajaran yang ada di PAUD haruslah bersifat menyenangkan dan disukai oleh para anak-anak, dan tidak bersifat membosankan. Salah satu caranya adalah melalui belajar sambil bermain, karena anak usia dini itu sangat identik dengan bermain. Maka proses pembelajaran yang ada di PAUD pun disesuaikan dengan ciri khas dan karakteristik mereka. 
Realitas yang ada adalah desain pembelajaran yang digunakan kebanyakan masih berkutat pada pedekatan yang konvensional, yakni berpusat pada ranah kognitf peserta didik dan guru sebagai pusat dari pembelajarannya (Srinadi dkk., 2020, hlm. 3). Kegiatan pembelajaran yang diterapakan di PAUD, umumnya hanya mengedepankan unsur perkembangan kognitif saja, padahal dalam PERMENDIKBUD No 137 Tahun 2014 telah menjelaskan tentang STPPA, yang mencakup 6 aspek perkembangan anak. Tatkala proses pendidikan hanya di arahkan pada sala satu aspek, maka perkembangan yang ada pada anak akan menjadi kurang optimal.

Berdasarkan penjelasan diatas maka diperlukannya suatu model pembelajaran yang sesuai untuk anak usia dini, sudjana berpendapat dalam Muhammad Darkasyi, dkk (2014) bahwa kontribusi pendekatan mengajar sebagai instrumen untuk menghasilkan proses belajar mengajar yang menyenangkan (Darkasyi dkk., 2014, hlm. 23). Salah satu model pembelajaran yang tepat dan juga menyenangkan bagi anak usia dini yaitu model pembelajaran quantum learning. Quantum learning merupakan salah satu langkah pembelajaran yang dapat diaplikasikan pada pembelajaran di sekolah guna mempermudah anak-anak dalam belajar (Mira Juwita Novitasari, 2014, hlm. 19). Quantum Learning adalah sebuah model pembelajaran yang menyenangkan dan terstruktur dengan berbagai strategi, petunjuk, kiat-kiat, contoh implementasi di lapangan yang dapat dijadikan pedoman dalam sebuah pembelajaran (Mike Hernacki, 2016, hlm. 16). Model pembelajaran quantum learning tersebut dapat menjadi suatu solusi bagi para guru dalam kegiatan pembelajaran, seperti quantum learning pada topik tiga membahas, tentang bagaimana cara seseorang dalam membangkitkan semangat belajar, dan menemukan manfaat belajar bagi dirinya, sehingga dengan demikian proses pembelajaran menjadi lebih menyenangkan dan tujuan pembelajaran yang sudah ditentukan dapat terpenuhi secara optimal. Pendapat tersebut sesuai dengan apa yang jelaskan oleh Mike Hernacki Bobi De Porter dalam bukunya yang berjudul "Quantum Learning (Membiasakan Belajar Nyaman dan Menyenangkan", “Quantum Learning merupakan kiat, petunjuk, langkah (strategi) dan semua proses belajar yang bisa mengasah pengertian (pemahaman) dan ingatan, dan menjadikan belajar sebagai suatu proses yang membahagiakan serta bermanfaat". Oleh sebab itu, pembelajaran quantum learning bisa ketegorikan sebagai suatu model pembelajaran yang memfokuskan pembelajarannya agar memberikan manfaat yang berarti bagi para anak didik, selain itu model pembelajaran quantum learning juga mempunyai fokus terhadap kebahagian (kesenangan) para anak didik (Deporter \& Hernacki, 2016, hlm. 54). 
Berdasarkan permalasahan yang sudah disebutkan diatas, penulis tertarik untuk mengkaji lebih dalam terkait, "Penerapan Model Quantum Learning Dalam Pembelajaran Anak Usia Dini” hal ini disebabkan model pembelajaran quantum learning di pandang sangat sesuai untuk di aplikasikan pada lembaga pendidikan anak usia dini, karena proses pembelajaran yang dilakukan dengan menggunakan model quantum learning bersifat menyenangkan dan tidak membosankan.

\section{Metodologi}

Dalam penelitian ini menggunakan penelitian yang berjenis studi pustaka (library research) yang akan mengalisis beberapa teori dari kepustakaan yang membahas tentang penerapan model pembelajaran quantum learning di lembaga pendidikan anak usia dini. Penelitian studi kepustakaan merupakan berbagai aktivitas yang berhubungan akan metode pengumpulan data pustaka, dengan cara membaca, mencatat, menelaah, serta meneganalisis dan mengolah data agar mengahasilkan suatu penelitian yang baru. Peneliti melakukan suatu perlakukan (tindakan) dalam melaksanakan penelitiannya yang menggunakan berbagai sumber kepustakaan yang bertujuan untuk memperoleh data/informasi yang diinginkan itu dikatakan sebagai riset pustaka (Zed, 2008, hlm. 3).

Pendekatan penelitian yang digunakan berupa kualitatif. Menurut Sugiyono, penelitian kualitatif pada umumnya dibuat berdasarkan masalah yang ditentukan. Sugi yono berpendapat tentang penelitian kulitatif dalam bukunya menjelaskan bahwa penelitian kualitatif lebih cenderung berfokus terhadap konsep teori yang akan dibahas (Sugiyono, 2015, hlm. 58). Sumber data dalam penetian ini diambil dari beberapa hasil analisis litarature dan didasarkan pada beberapa penelitian terdahulu (Sugiyono, 2015, hlm. 11). Sedangkan teknik pengumpulan data dalam penetian ini dilakukan dengan menganalisis teori-teori yang didasarkan atas buku-buku, jurnal ilmiah, web, dan lainnya yang ada hubungannya dengan tema penelitian yang akan dikaji. Penelitian ini dilakukan untuk mengetahui penerapan model pembelajaran quantum learning di lembaga pendidikan anak usia dini. Adapun langkah-langkah penelitian kepustakaan diantaranya:

a. Mengumpulkan mengenai data-data yang relevan melalui buku-buku, dokumen, jurnal maupun majalah internet. 
b. Menganalisa atau mengamati data-data yang akan diteliti, sehingga peneliti dapat menyimpulkan masalah yang akan dikaji secara lebih terperinci.

Dalam penelitian ini teknik pengumpulan data dilakukan dengan cara dokumentasi. Dokumentasi merupakan cara memperoleh data melalui berbagai dokumen. Data yang didapatkan dari teknik dokumentasi cenderung merupakan data sekunder yakni berisi suratsurat, laporan ataupun teori-teori para ahli (Usman \& Akbar, 2014, hlm. 56). Jadi, dapat dinyatakan bahwa dokumentasi merupakan kelengkapan yang disediakan berupa dokumendokumen tertentu yang diperlukan dalam proses penelitian yang sudah dilakukan.

Teknik analisis data dalam penelitian ini didasarkan atas teori dari Miles dan Hiberman. Teknik analisis data dilakukan bertujuan untuk mengetahui model quantum learning dalam pembelajaran anak usia dini. Jadi, penelitian ini akan dilakukan melalui proses studi kepustakaan atau metode kepustakaan, sehingga data-data akan diperoleh da ri hasil analisis buku-buku dan jurnal-jurnal ilmiah.

\section{Hasil dan Diskusi}

Berdasarkan hasil analisis yang telah peneliti lakukan dalam penelitian ini terhadap studi pustaka dengan mengakaji berbagai dokumen yang berkaitan tentang fokus kajian ini, ditemui beberapa poin penting dalam rangka mengimplementasikan pembelajaran quantum learning pada lmebaga PAUD. Pertama adalah terkait pemahaman konseptual mengenai pembelajaran quantum learning, prinsip pembelajaran quantum learning dan imlementasinya. Kedua adalah mengidentifikasi manfaat dalam implementasinya pembelajaran quantum learning di tingkat PAUD. Pemahaman konseptual mengenai pembelajaran quantum learning akan memberikan jalan terang mengenai proses desain pembelajarannya sehingga lebih mudah dalam proses implementasinya. Sementara itu, manfaat yang ada akan menjadi bahan pertimbangan untuk proses desain pembelajaran implementasinya di ranah PAUD.

\section{Pengertian Model Quantum Learning}

Model pembelajaran quantum learning adalah suatu gaya atau rancangan pembelajaran yang menyenangkan bagi semua anak. Karena model pembelajaran ini didesain dengan menggunakan berbagai metode dan ideologi belajar yang dapat ditera pkan 
oleh semua tingkatan usia. Mulai dari PAUD yang paling dasar hingga tingkat Perguruan Tinggi. Oleh sebab itu, model pembelajaran quantum learning ini dapat diterapkan di berbagai jenjang pendidikan, mulai dari yang paling dasar sampai dengan yang paling atas. Model quantum learning ini digunakan oleh guru sebagai bahan ajar yang inovatif serta kreatif dalam proses penggunaannya (Deporter \& Hernacki, 2016, hlm. 15).

Quantum Learning adalah suatu teknik yang digunakan anak-anak dalam kegiatan belajarnya yang dicetuskan oleh Potter. Dengan adanya quantum learning anak-anak dibawa kedalam suasana pembelajaran yang menyenangkan dan lebih nyaman. Dengan demikian secara tidak langsung anak-anak akan merasa lebih leluasa dan bebas dan kegiatan belajar tanpa merasa ada paksaan atau beban terhadap dirinya.

Menurut penulis model pembelajaran quantum learning adalah suatu desain model pembelajaran yang baru, yang dirangcang sesuai dengan kebutuhan para anak-anak dengan cara membuat suasana pembelajaran menjadi lebih nyaman dan menyenangkan, sehingga menarik minat anak untuk belajar.

\section{Alasan Lahirnya Model Quantum Learning}

Quantum learning lahir dari usaha yang dilakukan oleh Dr. Georgi Lazanov, seorang guru berkebangsaan Bulgaria yang melakukan percobaan terhadap pendapat yang mengatakan tentang "suggestology" atau "Suggestopedia". Prinsip dari pendapat tentang sugesti tersebut menjelaskan bahwa sugesti mampu serta bisa mempengaruhi hasil suasana belajar, dan keseluruhan dari semua sesuatu memberikan sugesti positif ataupun negatif. Adapun beberapa cara yang dilakukannya adalah mengajak anak-anak untuk duduk dengan tenang dan nyaman sambil mendengarkan musik latar yang diputarkan dalam kelas yang bertujuan untuk membangkitkan partisipasi pribadi, pada saat diperlihatkan poster-poster yang dijelaskan oleh para guru yang sudah terlatih dalam seni pengajaran sugestif terkait informasi yang terkandung dalam berbagai poster tersebut.

Adapun padanan kata lain yang menyerupai dengan kata suggestologi adalah "pemercepatan belajar" (accelerated learning). Pemercepatan belajar diartikan sebagai "memungkinkan anak didik belajar dengan kecepatan yang luar biasa dan dibarengi dengan rasa yang menggembirakan hatinya pada saat proses belajar terjadi. Teknik tersebut dapat menyatukan unsur-unsur yang secara sepintas terlihat tidak memiliki persamaan, hiburan, game, warna, cara berfikir positif, kebugaran fisik, dan kesehatan emosional. Akan tetapi seluruh unsur tersebut bekerjasama guna memberikan pengalaman belajar yang efisien. 
Quantum learning meliputi bagian-bagian penting dalam neurologistik (NLP), yakni suatu penelitian terkait bagaimana otak mengatur informasi. Penelitian ini mengakaji tentang hubungan antara bahasa dan perilaku bisa dipakai untuk menghasilkan hubungan pemahaman antara pendidik dan peserta didik. Guru-guru yang mempunyai pemahaman tentang NLP memahami bagaimana penggunaan bahasa yang tepat untuk mengembangkan perilaku-perilaku positif, yang merupakan faktor penting untuk menstimulasi fungsi otak yang paling efesien. Keseluruhan tersebut bisa juga menghasilkan serta memperlihatkan gaya belajar terbaik dari setiap orang dan menghasilkan "pegangan" pada saat menca pai keberhasilan dan keyakinan.

Jadi Bobbe de Porter dan Mike Henarki mengartikan bahwa model pembelajaran quantum learning adalah sebuah falsafah dari interaksi-interaksi yang mengubah tindakan untuk mencapai sebuah tujuan yang telah ditentukan dengan jalan yang menyenagkan. Tubuh kita secara fisik adalah materi. Sebagai pelajar, tujuan kita adalah meraih sebanyak mungkin keberhasilan-keberhasilan yang kita inginkan untuk kita nikmati didalam hidup kita kelak (Deporter \& Hernacki, 2016, hlm. 14-16).

Quantum learning juga memadukan antara suggestologi, cara belajar cepat, serta NLP dengan teori, keyakinan, dan metode yang tepat. Adapun yang tergolong dalam konsepkonsep kunci dari berbagai teori belajar antara lain adalah sebagai berikut:
a. Teori otak kanan dan otak kiri
b. Teori otak tri in one (3 in 1)
c. Pilihan modalitas (visual, auditori, dan kinestetik)
d. Pendidikan menyeluruh (holistik)
e. Belajar dari pengalaman
f. Belajar dengan simbol (metaphoric learning)
g. Rangsangan atau permainan

Adapun yang menjadi maksud dari delapan aspek kunci dalam quantum learning tersebut adalah untuk mengkolaborasikan antara aktivitas bermain dan bekerja secara setara dengan kecepatan yang luarbiasa dan diimbangi dengan kegiatan yang menyenangkan serta bersifat efisien yang dapat diterapkan oleh semua usia.

Penggunaan model pembelajaran quantum learning diharapkan dapat memperbaiki keadaan pembelajaran yang menakutkan agar menjadi lebih menyenangkan dengan demikian peserta didik lebih mudah mencapai kemampuan yang diinginkan. Pembelajaran 
quantum learning menciptakan suasana kelas yang lebih hidup yang membuat para anak didik cenderung lebih aktif, yakni tidak hanya sebatas pengamat yang pasif (Widyaningsih \& Yusuf, 2015, hlm. 682).

Ada beberapa hal yang harus diperhatikan dalam quantum learning, yaitu: setiap peserta didik diperkenalkan dengan "kekuatan pikiran" yang tak terbatas. Dalam teori pembelajaran quantum learning dijelaskan bahwa otak manusia mempunyai potensi yang sama seperti milik Albert Einstein. Hal lain yang dijelaskan dalam quantum learning adalah terkait bukti fisik dan ilmiah yang mencerminkan tentang cara otak bekerja. Berdasarkan hasil penlitain global learning mengenalkan bahwa jalan belajar itu menyerupai cara bekerjanya otak anak yang berusia 6-7 tahun seperti spons yang menyerap semua fakta, sifat-sifat fisik, dan kerumitan bahasa yang sulit dimengerti, dengan teknik yang membahagiakan (menyenangkan) dan bebas stres atau tanpa tekanan dan paksaan. Bagaimana faktor feedback dan stimulus dari lingkungan telah memberikan keadaan yang sempurna untuk belajar apapun. Dari pemaparan tersebut terlihat bahwa gagal dalam belajar bukan berarti sebuah halangan, akan tetapi keyakinan untuk terus berusaha bangkit adalah poin paling penting untuk mencapai suatu keberhasilan, jadikan kegagalan sebagai motivasi serta pendorong untuk menjadi lebih baik dari sebelumnya. Pada saat sudah mencapai keberhasilan, maka berilah reward atas keberhasilan tersebut, atau berikan penghargaan atas prestasi diri dengan cara membahagiakan diri.

\section{Prinsip dan Implementasi Quantum Learning}

Quantum learning memiliki prinsip yaitu semuanya berbicara, semuanya bertujuan, pengalaman sebelum pemberian nama, mengakui setiap usaha, jika layak dipelajari maka layak pula dirayakan (Astuti, 2017, hlm. 126) mengajak anak-anak agar memasuki dunia guru dan para guru dapat berperan dalam dunia anak-anak. Prinsip ini meminta agar pendidik mampu masuk kedalam dunia anak-anak sebagailangkah awal. Memasuki terlebih dahulu dunia anak-anak bermakna akan memberi izin untuk memimpin, menuntun, dan memudahkan perjalanan anak-anak menuju kesadaran dan ilmu pengetahuan yang lebih luas. Dengan melibatkan apa yang diajarkan oleh guru dengan sebuah peristiwa, pikiran atau perasaan yang didapatkan dari kehidupan rumah, sosial, atletik, musik, seni, rekreasi atau akademis mereka. Setelah kaitan itu terbentuk, dengan mudah dunia anak-anak dibawa ke dunia pendidik (Fathurrohman, 2017, hlm. 187). 
Pendidik juga bisa menggunakan berbagai pengalaman dari anak-anak sebagai titik tolaknya. Berdasarkan teknik tersebut akan mempermudah pendidikan dalam meberikan pembelajaran kepada para anak-anak baik dalam bentuk memimpin, mendampingi, serta mempermudah anak-anak mencapai pengetahuan yang lebih luas (Sugiyanto, 2010, hlm. 79).

Memperhatikan pada prinsip yang telah dijelaskan, maka pembelajaran quantum dapat diimplementasikan melalui beberapa langkah (Choiro \& Shodiqoh, 2018, hlm. 8). Pertama adalah dengan memberikan pemahaman akan relasi diri peserta didik dengan berbagai hal yang akan dihadapinya, yakni melalui penanaman "AMBAK" atau "Apa Manfaatnya Bagiku". Kedua melalui penataan lingkungan belajar yang baik agar kondusivitas pembelajaran dapat terjaga. Ketiga melalui pemupukan sikap mandiri dan kepercayaan diri agar semangat belajar para peserta didik tetap terjaga. Keempat melalui penyediaan proses pembelajaran yang memberikan pilihan gaya belajar bagi peserta didik, yakni adanya proses pembelajaran yang mengakomodasikan gaya belajar audio, visual maupun kinestetik. Kelima, yakni dengan membiasakan peserta didik untuk mencatat dan membaca atau dalam kata lain pembiasaan aktivitas literasi. Keenam yaitu melatih daya kreatif pada peserta didik, yakni dengan membiasakan peserta didik untuk terbiasa memunculkan ide-ide kreatif melalui bimbingan guru. Ketujuh adalah dengan melatih kemampuan ingatan peserta didik, kemampuan ingatan yang dimaksud yaitu kemampuan untuk mengingat dengan baik yang dilatih melalui proses menghafal yang kreatif.

Ketujuh langkah yang penulis infersikan di atas dapat sepenuhnya dijadikan sebagai haluan untuk mendesain proses pembelajaran bagi para guru. Dalam ranah PAUD di sekolah, kunci dari proses mendesain ini ada pada perencanaan kegiatan pembelaaran atau disebut dengan Rencana Pelaksanaan Pembelajaran (RPP) sesuai dengan kurikulum yang ditetapkan. Penyusunan RPP di PAUD sebagaimana dikatakan oleh Munawwaroh adalah terkait dengan proses merencanakan kegiatan bermain secra operasional untuk menyokong proses pembelajaran bagi para peserta didik (Munawaroh, 2020, hlm. 165). Ketujuh langkah dalam implementasi pembelajaran quantum learning tersebut sangat mungkin dilakukan dalam ranah PAUD tergantung bagaimana kompetensi guru dalam memahami pembelajaran quantum learning dan langkah implementatifnya. Oleh karena itu, maka dapat dikatakan bahwa guru yang mampu menanamkan AMBAK, melatih sikap positif dan 
melatih kebiasaan edukatif dan kreatif akan membuat peserta didik belajar dalam bingkai pembelajaran quantum learning.

\section{Manfaat Quantum Learning}

Quantum learning juga memberikan manfaat bagi anak-anak, adapun manfaatnya yaitu membuahkan kesadaran akan pentingnya belajar, sebab dalam pembelajaran tersebut dikemas dalam situasi yang menggembirakan dan juga menyenangkan. Pada setiap diri anak akan ditanamkan kekuatan seperti motivasi untuk melakukan sesuatu karena datangnya kekuatan AMBAK (Apa Manfaatnya Bagiku) (Sari, 2013, hlm. 29). Menurut Bobi De Porter dalam bukunya menjelaskan tentang manfaat quantum learning yaitu menjadikan peserta didik bersikap positif, termotivasi, menemukan cara yang tepat untuk belajar, menciptakan lingkugan belajar yang holistik, membuat peserta didik mampu membaca dengan cepat, menimbulkan kepercayaan diri para peserta didik, serta hasil belajarnya akan meningkat.

\section{Penutup}

Proses pembelajaran akan berlangsung dengan baik apabila didalam suatu proses pembelajaran dilaksanakan dengan cara yang menyenangkan dan tanpa ada unsur memberatkan anak-anak. Proses pembelajaran yang berada di PAUD membutuhkan suatu model pembelajaran yang tepat, yang bisa diterapkan dilembaga pendidikan anak usia dini yang sesuai dengan karakteristik serta kebutuhan mereka. Anak usia dini sangat identik dengan bermain, maka oleh karena itu metode yang tepat untuk mereka adalah belajar sambil bermain.

Salah satu desain model pembelajaran yang mengandung unsur tersebut adalah model pembelajaran quantum learning. Model pembelajaran quantum learning ini didesain sesuai dengan kebutuhan peserta didik dan dapat diterapkan diberbagai umur serta lembaga pendidikan. Model quantum learning dipercaya dapat meningkatkan motivasi atau minat belajar anak, kerena proses pembelajaran yang diterapkan didalam model quantum learning tidak bersifat memaksa akan tetapi lebih kepada membuat siswa atau anak-anak nyaman dengan suasana belajar yang menyenangkan. Dengan demikian maka akan mempermudah guru maupun anak-anak dalam mencapai tujuan pembelajaran yang telah ditentukan. Hal tersebut akan terjadi 
ketika guru mampu mengaplikasikan langkah-langkah pembelajaran quatum learning dalam proses pembelajaran yang didesain dan dijalankan.

\section{Daftar Pustaka}

Astuti, W. (2017). Model Quantum Learning untuk Meningkatkan Hasil Belajar Pecahan. Briliant: Jurnal Riset dan Konseptual, 2(2), 124-129. https://doi.org/10.28926/briliant.v2i2.41

Choiro, U. D., \& Shodiqoh, M. (2018). Quantum Learning Sebagai Upaya Guru Pendidikan Anak Usia Dini Menjadi Pendidik yang Menyenangkan. Tadris :Jurnal Penelitian dan Pemikiran Pendidikan Islam, 11(1), 103-111. https://ejournal.iainutuban.ac.id/index.php/tadris/article/view/18

Darkasyi, M., Johar, R., \& Ahmad, A. (2014). Peningkatan Kemampuan Komunikasi Matematis dan Motivasi Siswa dengan Pembelajaran Pendekatan Quantum Learning pada Siswa SMP Negeri 5 Lhokseumawe. Jurnal Didaktik Matematika, 1(1), 21-34. https://doi.org/10.24815/dm.v1i1.1336

Deporter, B., \& Hernacki, M. (2016). Quantum Learning (Membiasakan Belajar Nyaman dan Menyenangkan). Kaifa.

Fathurrohman, M. (2017). Model-Model Pembelajaran Inovatif. Ar-Ruzz Media.

Mike Hernacki, B. D. P. (2016). Quantum Learning Membiasakan Belajar Nyaman dan Menyenangkan). PT. Kaifa.

Mira Juwita Novitasari. (2014). Penerapan Model Quantum Learning Untuk Meningkatkan .... Jurnal Pendidikan Seni Rupa, 2, 18-23.

Munawaroh, M. (2020). Kompetensi Menyusun Rencana Pelaksanaan Pembelajaran (RPP) Melalui Bimbingan Berkelanjutan Pada Guru Taman Kanak-Kanak Masjid Agung Lampung Selatan. Lentera: Jurnal Ilmiah Kependidikan, 13(1), 163-174. https://doi.org/10.12345/lentera.v13i1.525

Sari, M. (2013). Penerapan Model Quantum Learning untuk Meningkatkan Kualitas Pembelajaran Materi Energi Panas dan Bunyi Siswa Kelas IV Sekolah Dasar Negeri Randugunting 4 Kota Tegal [Skripsi, Universitas Negeri Semarang]. https://lib.unnes.ac.id/17351/

Shofa, M. F., \& Suparno, S. (2014). Peningkatan Keterampilan Berbicara Anak Usia Dini Melalui Permainan Sandiwara Boneka. Jurnal Pendidikan dan Pemberdayaan Masyarakat, 1(2), 209. https://doi.org/10.21831/jppm.v1i2.2690

Srinadi, N. N., Agung, A. G., \& Yudana, I. M. (2020). Pengaruh Bimbingan Berkelanjutan Terhadap Kemampuan Melaksanakan Asesmen Autentik pada Guru. Jurnal Pedagogi Dan Pembelajaran, 3(1), 84-94. https://doi.org/10.23887/jp2.v3i1.24365

Sugiyanto. (2010). Model-Model Pembelajaran Inovatif. Yuma Pustaka.

Sugiyono. (2015). Metode Penelitian Pendidikan: Pendekatan Kuantitatif, Kualitatif, dan R\&D. Alfabeta.

Usman, H., \& Akbar, R. P. S. (2014). Pengantar Statistika. Bumi Aksara. 
Widyaningsih, S. W., \& Yusuf, I. (2015). Penerapan Quantum Learning Berbasis Alat Peraga Sederhana Untuk Meningkatkan Hasil Belajar Peserta Didik. Jurnal Panrita, 10(3), 680-693.

Zed, M. (2008). Metode Penelitian Kepustakaan. Yayasan Pustaka Obor Indonesia. 